\title{
WASHC5 wt Allele
}

National Cancer Institute

\section{Source}

National Cancer Institute. WASHC5 wt Allele. NCI Thesaurus. Code C112063.

Human WASHC5 wild-type allele is located in the vicinity of 8q24.13 and is approximately $68 \mathrm{~kb}$ in length. This allele, which encodes WASH complex subunit strumpellin protein, plays a role in the induction of actin polymerization. Mutations in this gene are associated with autosomal dominant spastic paraplegia 8. 